American Journal of Applied Sciences 9 (10): 1668-1677, 2012

ISSN 1546-9239

(C) 2012 Science Publication

\title{
The Influence of Clients' Qualities on Green Design Performance of Building Projects in Malaysia-Descriptive Study
}

\author{
Mohamed S. Elforgani and Ismail Rahmat \\ Department of Built Environment, Faculty of Architecture Planning and Survey, \\ University Technology MARA, Shah Alam, Malaysia
}

\begin{abstract}
Problem statement: In the construction industry, success of building projects greatly depends on the client's performance. The performance of clients is crucial since decisions made will influence the overall project performance. Typically, clients are represented by managerial and technical representatives during the design process. They play major roles in conveying required information to the design team regarding their future project. The quality of clients' representatives has potential influence on design team performance. In designing green buildings client's attributes are critical factors to high performance of building projects. Attributes such as knowledge and experience on green buildings, commitment level to green and clients' ability to participate and manage design process are the key factors to produce green design. The propose of this study to identify current performance level of clients of building projects and establish key clients' attributes influencing green design performance. Approach: To achieve mentioned aim a questionnaire survey was conducted to collect dada required. A sample of 274 respondents has been covered under the study, including architects and engineers practicing design and consultancy building sectors. Prior to analysis of data WINSTEPS software were used for Rasch modeling to determine validity and reliability of date. Descriptive analysis data includes quantitative and qualitative. Results and Conclusion: Client qualities in general were low, client communication with design team; client involvement and ability to coordinate design process were moderate. However, Knowledge and experience on green design, client organization commitment to green and commitment in financing green design were low. The result indicates that most building clients have inadequate knowledge to manage design green buildings. Therefore, more education and training courses on green building are needed to cope with green design requirements. The client requires improving the coordination and involvement level to ensure all client requirements were identified. Regular meeting is the efficient method to communicate with a client.
\end{abstract}

Key words: Green design, Clients' qualities, green design performance

\section{INTRODUCTION}

Client qualities refer to attributes or characteristics of the client or his/her representatives through their participation in the design and construction process (Kometa et al., 1996). In this study, Clients' attributes refer to the qualities and characteristics of the client during the design stage of green buildings.

Kometa et al. (1997) and Ahmed (2007) observed that the success of building projects greatly depends on the client's performance level. These findings were supported by Haponava and Al-Jibouri (2010) who also found that decisions made by clients during the design stage affect as much as 80 percent of construction cost. Typically, clients are represented by managerial and technical representatives during the design process. They play major roles in conveying required information to the design team regarding their future project (Barrett and Stanley, 1999).

Drawing from literature concerning client's qualities of building projects, a number of studies have investigated potential client's qualities as critical factors to high performance of building projects (Chan et al., 2003; Fortune and White, 2006; Haghnazar and Sepehri, 2010; Ling, 2004; Toor and Ogunlana, 2009). The factors were discussed from different perspectives and were classified differently. Throughout this study, client qualities will be classified into key categories (i.e. quality of personnel, quality of managing the design process and quality of the client's organization).

Corresponding Author: Mohamed S. Elforgani, Department of built Environment, Faculty of Architecture Planning and Survey, University Technology MARA, Shah Alam, Malaysia 
Review of literature on Cients' qualities: In the construction industry, over the years, studies have paid little attention to client's performance compared with studies related to the performance of contractors and the supply chain. The performance of clients is crucial since decisions made will influence the overall project performance. Adams (1999) mentioned that the performance of clients has not been sufficiently researched. This view is echoed by Egbu and Ilozor (2007) who mentioned that there is still a lack of research pertaining to the comprehension of the client's key roles.

The influence of client qualities on consultant's performance during project implementation was investigated by Kometa et al. (1996) identified 47 client's qualities through the lifecycle of project implementation. In another study, Kometa et al. (1997) presented ten vital client related qualities that may influence the performance of a project. The qualities presented were organizational quality of client, characteristics of the client, previous performances, previous experience of client, project characteristics, feasibility of the project, stability of finance ability, client's duty, market condition and management quality. Yean (2002) also investigated the extent to which client related attributes contribute to the performance of a project. Their research concentrated on the influence of clients' attributes during the project lifecycle and how they affected project performance.

The technical representative, who is commonly the client's project manager, has the responsibilities to manage the collection of functional and operational information to develop client requirements and to review and approve design solutions with the design team. In this context, Ahmed (2007) mentioned that in order to effectively manage the design process, client representatives are required to have wide knowledge in construction, leadership and organization skills. The present study will concentrate on the influence of client's knowledge, experience and commitment on the green design performance of building projects.

Clients' knowledge on green buildings: According to Ahmed (2007), during the design stage, the client is required to possess firstly, knowledge concerning the mission of their organization and to understand their operations. Secondly, knowledge and experience in building construction. The client is the key person to provide information concerning the business mission and the goal and context of the organizational structure as well as the overall aim of the project. When the client is knowledgeable in their organization's mission and their operation, he could provide the required design information to the design team (Barrett and Stanley, 1999).

A knowledgeable client in green building aspects will plan the development of the requirements parallel to the business strategies of their organization. This guarantee the client obtained the necessary information appropriately to the organization. On the other hand, a client unknowledgeable in implementing different construction levels is unable to enroll into green aspects and understand what to expect and how to play their roles and responsibilities. In this context, Alinaitwe (2008) found that more than $90 \%$ of building clients do not support training on green design aspects in their organization. That reveals the lack of knowledge and skills in client's representatives during the design process of green buildings. These findings were supported by Gaia (2004) who highlighted that most clients should give more consideration to training to increase knowledge concerning green design issues.

Clients' experience on green buildings: Client experience plays a major role in affecting the performance of a design team (Pheng and Chuan, 2006) and on the performance of building projects (Ling, 2004). Soetanto et al. (2000) evaluated the qualities of UK clients and found that the client's past performance and experience is one of three qualities that significantly affect overall project performance. These findings were supported by Ahmed (2007) who found that the level of client experience has a major impact on project success.

Designing green buildings is more complex than designing conventional buildings. To understand the complexity of activities during the design process is very difficult (Girard and Robin, 2006; Knudstrup and Hansen, 2005; Newton, 2008a). Due to the complexity of the design process, the effort applied to planning and control is commonly either insufficient or inappropriate (Tilley, 2005). Thus, more knowledge and experience are needed to cope with green design requirements

Clients' commitment to green buildings: According to Abdullah and Ramly (2006), Client commitment refers to the seriousness of the clients' organization to implement the project and preparedness to provide the required resources and support to accomplish the project successfully including the client's commitment to appoint fulltime representatives. It is vital to provide a point of contact for the client with project stakeholders. Currently clients are usually represented by organized technical teams. However, the overall project outcomes greatly depend on the attention level and participation effectiveness of client representatives during project implementation. 
Am. J. Applied Sci., 9 (10): 1668-1677, 2012

High client commitment is required especially at the early design stage in order to ensure clear identification of the client requirements. Gaia (2004) stated that client commitment and direction is significant in the early stages of the project. Client commitment is very significant and depends on the purpose, priorities and capital invested. In this context, many studies have confirmed that the project performance have a direct influence on the commitment level of the client in the construction project.

The initial step in the process of achieving a green building project is to confirm the required commitment on the part of the client. Shafii and Othman (2007) stated that to move towards green building, building owners and clients should be more committed to disseminating green construction. Yudelson (2008) discussed the cost effectiveness of green building design and mentioned that early client commitment to green building is crucial to achieve a high performance building.

In conclusion, design teams may offer for the client to incorporate green features in design but the client should be committed to greenness. Most clients like to apply green features but at the same time, they dislike paying more for it. Lastly, the implementation of green aspects during the design stage will increase if the client imposes green aspects in his brief.

Client's capability of managing design process: Designing green buildings requires a set of tasks to be identified, recognized, assigned across the team, arranged and integrated properly into the design team process. Ahmed (2007) mentioned that in managing the design process, the clients are required to clarify goals and objectives of the project and to coordinate efforts with design team members. Karlson et al. (2008) mentioned that achieving green built environments successfully requires more involvement and collaboration among design team members and client representatives because the design teams can no longer work separately, concerned with only their work. This view was supported by Yudelson (2008) who also believes that effective involvement and coordination among project stakeholders is one of the vital elements to enhance the performance of green design.

Organizing Clients' project team during design process: Efficient and effective management of building projects requires strong leadership skills (CABE, 2003). Selecting the right individuals for a project team is essential for high-quality attributes particularly during the design phase. Ahmed (2007) mentioned that the quality of both, the client's representatives and the design team influences the development of client requirements and encourages a strong commitment within the client's organization and among project participants. Thus, the client's representatives are required to have strong leadership skills to organize the whole project process to be systematic, efficient and effective.

Coordinating and encouraging the green design process within a project team requires competent leadership. Songer and Molenaar (1997) established that teamwork ensures a successful outcome for project stakeholders including clients and their representatives who share a clear understanding of the project constraints and technical performance required. Ahmed (2007) stated that the client representative who is working as Project Manager is required to be able to put things in order although he/she may not be technically knowledgeable in the construction process.

Communication effectiveness with design team: The nature of the design process requires effective communication to allocate all the requirements and to enable throughout consideration of all possible crucial issues (Yahya and Rahman, 2007). Communication during the design process is an iterative in nature, which needs shared understanding and commitments from the client and other project participants involved. It is a dynamic process that continues during the early design phase of the building project and develops from general to more detailed features as it progresses.

In this context, Love (2002) mentioned that the utilization of Information Communication Technologies (ICTs) is one of the most important means of improving the performance of design and construction teams. Damodaran and Shelbourn (2006) found that ICTs expand participation and collaboration among project stakeholders. This view is echoed by Danielle (2007) who recommended the adoption of a design charrette as a regular mechanism to promote efficient communication and collaboration.

It could be concluded that the design process of green buildings is more complex than the design process of conventional buildings. Efficient and effective coordination, collaboration and communication among client and other project participants is required to overcome complexity and difficulty inherent within the design process of green buildings. The client's representatives are required to have management skills in order to be able to organize and coordinate the design process effectively with the design team and other project participants. 
Commitment of client organization: Organizational commitment has a significant influence on overall employee behaviors and performance effectiveness in organizations. Management style in the organization can influence the commitment level of individuals. Therefore, whole management culture and style determined by the top management's actions are strongly associated with the commitment level of individuals working in the organization. An organization's commitment to provide sufficient required resources is essential to team and work effectiveness. Lack of resources is frequently a major cause of inadequate team performance.

Commitment to providing finances for green building: Drawing from the literature regarding client commitment, many researchers stated that client commitment includes providing finances and fulltime representatives to the project, maintaining active participation, top management support for the project, effective decision making and communication (Barrett and Stanley, 1999; CABE, 2003; GPN, 2003; Yu and Shen, 2006). Sufficient project funds should be allocated from the outset by the client. Ahmed (2007) mentioned that funds allocated by the client for the project is the key restriction that outlines the parameter of the project such as the client's requirements being balanced with resources available. Without the commitment of the client's organization in providing the necessary funds, uncertainty in project implementation will be increased. In this context, the clients must be committed to providing a responsible fulltime representative to work as the contact point by providing required information to the design team. Barrett and Stanley (1999) stated that to ensure effective commitment, clients require strategic management to coordinate different personnel involved within the organization.

To apply green design issues effectively requires client commitment. Most building clients believe that implementing green issues in buildings impose additional cost. Therefore, they are avoiding the incorporation of green features in design particularly if they are expensive. Uhl and Anderson (2001); Kibert (2007) and Owens et al. (2006) found that one of the key barriers of integrating green innovation into the building industry is lack demand from the client. Megat (2006) confirmed that the low commitment from top management and lack of resources allocated to green issues play as major barriers to green built environments in Malaysia.

Maintaining active participation in green design process: The significance of team member participation to the performance of the organization has been shown in many studies. Rahmat (1997) stated that team participation can enhance collaboration, performance, communication, resource utilization, decision-making, team commitment, member confidence and quality. These findings were supported by Belanger and Allport (2008) mentioned that perceived member involvement among teams in decision-making was positively associated with team cohesiveness, team productivity and an enhancement of team communication. Regarding this issue, Vandenberg and Richardson (1999) confirmed that high-involvement processes influenced organizational effectiveness through a positive impact on employee morale. On the other hand, Hodson (2002) found that all forms of team member participation offered improved experiences and reduced conflicts. Furthermore, team participation assists members to identify team aims and goals to be achieved (Albanese, 1994).

The design of building projects is a complex process and thus, difficult to manage. Design requires effective participation and collaboration from a huge and diverse collection of individuals and organizations. Therefore, managing the design process requires huge efforts to manage the participants, specific activities and the flow of information between them (Tilley, 2005). Newton (2008b) believes that design managers should encourage collaborative work through understanding and managing the dynamics of the team and recognizing the responsibilities that may be involved in supporting collaborative working dynamics. Furthermore, Girard and Robin (2006) mentioned that to effectively manage the design process, project managers should define collaboration among team members and define whether or not the collaboration required is being predetermined.

From the aforementioned literature, clients'qualities plays a major role on influencing the performance level of the design team and overall project performance. The key client qualities identified were quality level of the client and client representatives, quality of managing the design process and commitment level of the client organization.

\section{MATERIALS AND METHODS}

The study is part of $\mathrm{PhD}$ research, a triangulation technique was implemented, which combined quantitative and qualitative date collection approaches. The research was performed throughout three main stages, the first stage was a comprehensive literature review validated in a preliminary questionnaire survey. Data collection involving semi-structured interviews 
was the second stage. The main aim of this stage was to upgrade and refine the research problem and proposed theoretical framework. The last stage involved the final questionnaire survey, in which data was collected for statistical analysis purposes. Prior of this survey preliminary questionnaire was posted. Four research variables were verified.

To investigate performance of client's during design green buildings practice, in final questionnaire survey, the questionnaire was divided into two parts. The first part requires respondents to provide their personal particulars including their job title, experience, number of construction projects involved, type of buildings designed by his/her firm followed by type of procurement, type of building and size of the projects they have been carried out, whereas, the second part focuses on uncovering the current performance of buildings, clients and key design team.

A survey package consisting of the detailed questionnaire, post card, pen, stamped envelope and a covering letter explaining the objectives of the study was posted to professionals in various architectural consultancy firms as well as engineering consultancy firms, selected by the list of architects downloaded from the Malaysian Institute of Architects (PAM) website, whereas list of engineers provided from their organization directory of Association of Consulting Engineers Malaysia (AECM).

The population for this study became key design team players for architects registered with the PAM and Engineers registered with ACEM practicing consultancy services Table 1. Only architects registered in PAM and Engineers registered in AECM are selected as the research context. The target population includes architects and Engineers working in design consultancy located in Malaysia. The limitation parameters of the research considered were the minimum size of green building project, based on contract value, was set at RM2,000,000.00 and projects handled after January 1,
2003 were included in this study, this date was chosen because it was assumed that respondent who chooses projects handled before than this date may not have had all project details to complete the questionnaire.

A total of 274 survey questionnaire were distributed, 102 valid replies were received, which represents a response rate of $37.1 \%$. WINSTEPS software was used for Rasch Modeling of the Principal Performance Measures to examine data validity and reliability was analyzed. SPSS virsion19, software was used to analyses data collected. The technique of descriptive statistics was used to describe and make sense of the data. The descriptive statistics included the frequency, mean and standard division for studied variables.

Validity and reliability: Prior to analysis, functioning of the 5-point Likert scale was examined according to the criteria by Linacre (2006). More than 10 observations are found in each category. Table 1 shows the rating scale category function data for clients' qualities suggesting no category disordering. Beside, both the observed average measures and category measure are characterized by criterion of monotonic advance. The Outfit MNSQ values, which are close to infit MNSQ values, for each category are all close to 1.00 and less than 2.00, suggesting that each label was providing measurement information rather than noise in the data. The threshold estimates increase with the category label, indicating that the response categories were used in expected and intended manner. These evidences suggested that the rating scale categories are effectively satisfactory for clients' qualities variable.

Reliability and separation index: As can be seen from Table 2, reliability of all variables item difficulty measure was very high (0.98). This suggested that the ordering of item difficulty was highly replicable with other comparable sample from similar population.

Table 1: Key reliability and validity parameters of clients'qualities items

\begin{tabular}{|c|c|c|c|c|c|}
\hline Total variance in observations & Category measures & & & & Threshold estimates \\
\hline-3.52 & -4.75 & & & & - \\
\hline-1.93 & -2.5 & & & & -3.58 \\
\hline-0.33 & -0.04 & & & & -1.38 \\
\hline 1.01 & 2.5 & & & & 1.29 \\
\hline 2.60 & 4.83 & & & & 3.66 \\
\hline \multicolumn{6}{|c|}{ Rasch Principal Components Analysis (RPCA) } \\
\hline Total variance in observations & & & & $69.40 \%$ & \\
\hline variance explained by measures & & & & $64.90 \%$ & \\
\hline Unexplained variance in 2 ndcontrast & & & & $22.10 \%$ & \\
\hline \multicolumn{6}{|l|}{ Reliability and Separation index } \\
\hline Model RMSE & Mean & Adj-Sd & Separation & Reliability & \\
\hline Behavior measures & 0.66 & 0.17 & 1.06 & 2.42 & 0.85 \\
\hline Item measures & 0.16 & 049 & 1.18 & 7.31 & 0.98 \\
\hline
\end{tabular}


Am. J. Applied Sci., 9 (10): 1668-1677, 2012

Table 2: Item statistics: misfit order and item correlations

\begin{tabular}{|c|c|c|c|c|c|c|}
\hline \multirow[b]{2}{*}{ Variables } & \multicolumn{6}{|l|}{ MNSQ } \\
\hline & \multicolumn{2}{|c|}{------Outfit-------- } & \multicolumn{2}{|c|}{-----------Infit-------- } & \multicolumn{2}{|c|}{-------PTMEA----- } \\
\hline clients' & Lowest & Highest & Lowest & Highest & Lowest & Highest \\
\hline qulities & 0.7 & 1.37 & 0.69 & 1.3 & 0.66 & 0.76 \\
\hline
\end{tabular}

The item separation index was very high which are considerably higher than the minimum desired 2.00. The Adj-Sd was at accepted estimate. The item measure RSME measure was 0.16 which considered very well. Taken together, these statistics indicate good separation between items and item measures.

Dimensionality test of variables: For the clients' qualities with five-category response model as can be seen in Table 2, all items had acceptable out fit MNSQ statistics between 0.60 and 1.40 , the lowest outfit was 0.70 whereas the highest was 1.37 suggesting that it was not redundant items with considering high values may represent a lack of homogeneity with other items in the subscale. All items had high to very high PTMEA correlations (0.66-0.76) which exceeded .20 as critical value for the correlation. Positive sign of correlation values identified that the items are systematically correlated in the same direction, measuring the same latent variable calling "Client's qualities", therefore, all items had good discrimination.

\section{RESULTS}

Seven components of client qualities were descriptive statistically produced. Table 3 representing the mean variables of client's qualities along the several of dimensions. The lowest three rated dimensions were the client knowledge in green building, client experience in green building and client commitment in finance green building which was rated low. The fact that it were rated very low indicates that most of the client green buildings have no enough knowledge and experience to involve efficiently in the design process of green building projects.

The lowest three rated dimensions were the client knowledge in green building, client experience in green building and client commitment in finance green building which was rated low. The fact that it were rated very low indicates that most of the client green buildings have no enough knowledge and experience to involve efficiently in the design process of green building projects. It would have been expected that with literature major of clients insufficient knowledge and experience in terms of managing a green design process (Tilley, 2005; Shafii and Othman, 2007; Alinaitwe, 2008).
Table 3: Client's Qualities

\begin{tabular}{lllll}
\hline Code** & Items & Mean* & Rank & Score \\
\hline MDP2 & Client communication with design team & 3.30 & 1 & Moderate \\
CCO2 & Client Involvement during process & 2.97 & 2 & Moderate \\
MDP1 & Client ability to coordinate of design process & 2.89 & 3 & Moderate \\
CRQ3 & Client organization commitment to green & 2.60 & 4 & Low \\
CCO1 & Commitment in financing green design. & 2.39 & 5 & Low \\
CRQ1 & Knowledge on green design & 2.19 & 6 & Low \\
CRQ2 & Experience on green design & 1.88 & 7 & Very low \\
& Average & 2.60 & & Low \\
\hline
\end{tabular}

*; Key: 1-1. 8: very low 1.9-2.6: Low 2.7 -3.4: moderate 3.5-4.2: high 4.2-5.0: very hi **; CRQ: Clients' Representatives Quality, MDP: Managing Design Process, CCO: Client Commitment

Table 4: Client commitment to finance green issues

\begin{tabular}{lcc}
\hline Client commitment level & Frequency & Percentage \\
\hline Very low & 19 & 18.60 \\
Low & 39 & 38.20 \\
Moderate & 30 & 29.40 \\
High & 13 & 12.70 \\
Very high & 1 & 1.00 \\
Total & 102 & 100.00 \\
Mean & & 2.39 \\
\hline Key: & &
\end{tabular}

Key: 1-1.8 very low; 1.9-2.6 Low; 2.7 -3.4 moderate; 3.5-4.2 high; 4.2-5.0 very high

Table 5: Client involvement during design process

\begin{tabular}{lcc}
\hline Client involvement level & Frequency & Percentage \\
\hline Very low & 6 & 5.90 \\
Low & 17 & 16.70 \\
Moderate & 55 & 53.90 \\
High & 22 & 21.60 \\
Very high & 2 & 2.00 \\
Total & 102 & 100.00 \\
Mean & & 2.97 \\
\hline Key: 1-1.8 very low; 1.9-2.6 Low; 2.7 -3.4 moderate; 3.5-4.2 high; \\
4.2-5.0 very high
\end{tabular}

In the present study, knowledge of the client on green buildings during the design process was at low level $($ mean $=2.19)$ and the experience degree on design green buildings was very low $($ mean $=1.88)$. In terms of commitment level of the client toward applying green aspects in their building, the results implies that clients were low $($ mean $=2.60)$ committed for applying green building aspects.

To apply green design issues effectively requires client commitment. The design teams were asked to indicate the level of client's commitment in providing finance to ensure implementing green building issues. As Table 4 shows only $13.7 \%$ of clients were high/very high committed to providing finance to green building. In contrast, $56.8 \%$ of clients were low/very low commitment level to finance green building.

The quality of client communication with the design team was investigated the result as Table 5 suggests that the communication effectiveness between client's representative and design team was at moderate level (mean $=3.3$ ). The result implies that although the rate was high, the clients still require implementing an efficient communication technique with the design team. 
The client's ability level to maintain active participation in the design process was investigated using a five-point scale, very high to very low. The result appears in Table 5 shows that the client's participation was generally moderate (53.9\%). Only $22.6 \%$ of clients were highly/ very high participated during the design process. In contrast, $22.6 \%$ of clients their participation was low/very low.

In semi-structured interviews, all architect interviewees were mentioned that client involvement during the design process has vital influence on design performance. Client highly involved during an early stage of the design process when the client aimed to articulate and identify the project requirement. The involvement decreasing gradually as the design process implemented. Three M\&E engineers found that clients would encourage implementing green building aspects in designed building if the no additional cost would be occurred. One mechanical engineer mentioned that clients like innovation solutions that reduce initial cost and operation cost and they may would adopt it if the payback period is clear articulated in design team proposals.

In semi-structured interviews, four architect interviewees were mentioned that the client's representative's communication skills and green building requirement knowledge have major influence on the performance level of design green buildings. Similarly, three M\&E interview were agreed that client's representatives have to be competent with communication and coordination to articulate efficiently all client requirements and identifying clearly client objectives. Most of the interviewees agreed that regular meeting is the efficient method to communicate with a client.

\section{DISCUSSION}

It would have been expected that with literature major of clients insufficient knowledge and experience in terms of managing a green design process (Tilley, 2005; Shafii and Othman, 2007; Alinaitwe, 2008).

The performance of clients is crucial since decisions made will influence overall project performance. To effectively manage the design process, client representatives are required to have wide knowledge in construction, leadership and organization skills. The client is the key person to provide information concerning the business mission and the goal and context of the organizational structure as well as the overall aim of the project. The present study will concentrate on knowledge, experience and commitment of client and/or client representatives during the design stage in order to design green building projects.
The performance of clients is crucial since decisions made will influence overall project performance. To effectively manage the design process, client representatives are required to have wide knowledge in construction, leadership and organization skills. The client is the key person to provide information concerning the business mission and the goal and context of the organizational structure as well as the overall aim of the project. The present study will concentrate on knowledge, experience and commitment of client and/or client representatives during the design stage in order to design green building projects.

The result confirmed findings from Alinaitwe (2008) who highlighted the lack of knowledge and skills in client's representatives during the design process of green buildings. These findings were supported by Gaia (2004) who highlighted that most clients should give more consideration to training to increase knowledge concerning green design issues. The result implies that most building clients were not experienced in green buildings. The result implies also, most building clients have inadequate knowledge to manage design green buildings. The experience of clients was very not enough to manage design process effectively. The result implies the commitment level on green might lead to less involvement in design process of green buildings resulting to less knowledge and experience. To cope with green design requirement clients need to be more knowledgeable and experienced (Tilley, 2005). This is suggesting that clients require focusing on training their representatives to be knowledgeable on managing green design process.

The importance of client commitment was highlighted by many researchers (Gaia, 2004; Shafii and Othman, 2007; Abdullah and Ramly, 2006; Yudelson, 2008). Design teams will implement more green design aspects if the client was committed. Clients are usually represented by organized technical teams. However, the overall project performance greatly depends on the commitment level and of client representatives during project implementation (Nguyen et al., 2007). To move towards green building, building owners and clients should be more committed to disseminating green construction (Shafii and Othman, 2007). The result indicates that client needs to be more commitment for implementing green features in their buildings.

The result implies that finance commitment level to green building is still low, the result confirmed findings from (Anderson, 2000; Cooke-Davies, 2002; Eisenberger et al., 2001; Landman, 1999; Owen, 2003) who found that one of the key barriers of integrating green innovation into the building industry is lacking 
demand from the client. Further more the result supported Megat (2006) findings in which confirmed that the low commitment from top management and lack of resources allocated to green issues play as major barriers to green built environments in Malaysia.

Many of the quality and efficiency problems experienced during the design process are due to inadequate design management and poor quality control of the end product (Rounce, 1998). This was confirmed by Mayor and Tormenta (1999) who found that design process is managed using typical project management approaches and due to this, poor performance levels are being achieved. The three factors rated high were client communication with the design team, client involvement during green design process and client ability to coordinate of design process.

It could be concluded that client involvement during design process was moderate. The client participates actively during an early stage of the design process. The results confirm Karlson et al. (2008) findings who found that to apply successfully green building aspects require more participation from client and other project stakeholders. Successfully applying the green building concept needs more involvement and collaboration among key project participants because the designer can no longer work separately, concerned with only their work.

Designing green buildings requires a set of tasks to be identified, recognized, assigned across the team, arranged and integrated properly into the design team process. The result implies that the client ability level of controlling and organizing design process were moderate $($ mean $=2.89)$.

The result implies that although the design team agreed the quality of communication effectiveness with the client is acceptable. They believe that the client requires improving the coordination and involvement level. The result indicates the ability of client to manage the green design process at the moderate level and design team prefer to deal with knowledgeable and skilled representatives to ensure all client requirements were identified.

\section{CONCLUSION}

The client is the key person to provide information concerning the business mission and the goal and context of the organizational structure as well as the overall aim of the project. The result indicates that most building clients have inadequate knowledge to manage design green buildings. The result confirmed findings from (Alinaitwe, 2008) that highlighted the lack of knowledge and skills in client's representatives during the design process of green buildings. The lowest rated dimension was the client experience in green building which was rated low. The fact that it was rated low indicates that most of client green buildings have no enough experience to involve efficiently in design process of green building projects. The experiences of clients were very not enough to manage design process effectively. The result implies the commitment level on green building might led to less involvement in green building resulting to less knowledge and experience.

\section{REFERENCES}

Abdullah, W.M.W. and A. Ramly, 2006. Does successful project management equates to project success? Proceedings of the International Conference on Construction Industry, (ICCI' 06), Universiti Teknologi Malaysia, Malaysia.

Adams, S.G., 1999. An investigation of the attributes contributing to team effectiveness of engineering and science faculty. Proceedings of the 29th Annual Frontiers in Education Conference, Nov. 10-13, IEEE Xplore Press, San Juan, Puerto Rico, pp: 12A5/8-12A511. DOI: 10.1109/FIE.1999.839275

Ahmed, N., 2007. The influence of client's atrributes during briefing process on project success. Universiti Teknologi MARA, Shah Alam.

Albanese, R., 1994. Team-building process: Key to better project results. J. Manage. Eng., 10: 36-44.

Alinaitwe, H.M., 2008. An assessment of clients' performance in having an efficient building process in Uganda. J. Civil Eng. Manage., 14: 73-78. DOI: 10.3846/1392-3730.2008.14.1

Anderson, G., 2000. Government Accounting and Interim Budget Development Projects in Tanzania. 1st Edn., Department for Democracy and Social Development, Stockholm, ISBN-10: 9158689443.

Barrett, P. and C.A. Stanley, 1999. Better Construction Briefing. 1st Edn., John Wiley and Sons, Oxford, ISBN-10: 0632051027, pp: 168.

Belanger, F. and C.D. Allport, 2008. Collaborative technologies in knowledge telework: An exploratory study. Inform. Syst. J., 18: 101-121. DOI: $10.1111 / \mathrm{j} .1365-2575.2007 .00252 . \mathrm{X}$

CABE, 2003. Creating Excellent Buildings, Aguide for Clients. 1st Edn., On Line Books, London.

Chan, A.P.C., D.W.M. Chan and K.S.K. Ho, 2003. An empirical study of the benefits of construction partnering in Hong Kong. Constr. Manage. Econ., 21: 523-533. DOI: 10.1080/0144619032000056162 
Cooke-Davies, T., 2002. The "real" success factors on projects. Int. J. Project Manage., 20: 185-190. DOI: 10.1016/S0263-7863(01)00067-9

Damodaran, L. and M. Shelbourn, 2006. Collaborative working-the elusive vision. Arch. Eng. Design Manage., 2: 227-243. DOI: 10.1080/17452007.2006.9684619

Danielle, M., 2007. Design and sustainable commercial buildings.

Egbu, C.O. and D. Ilozor, 2007. Construction Clients and Industry Innovations: Understanding of their roles and impact.

Eisenberger, R., S. Armeli, B. Rexwinkel, P.D. Lynch and L. Rhoades, 2001. Reciprocation of perceived organizational support. J. Applied Psychol., 86: 4251. DOI: $10.1037 / 0021-9010.86 .1 .42$

Fortune, J. and D. White, 2006. Framing of project critical success factors by a systems model. Int. J. Project Manage., 24: 53-65. DOI: 10.1016/j.ijproman.2005.07.004

Gaia, 2004. A Client's guide to sustainable offices-a draft for development.

Girard, P. and V. Robin, 2006. Analysis of collaboration for project design management. Comput. Indu., 57: 817-826. DOI: 10.1016/j.compind.2006.04.016

GPN, 2003. An introductory study on green purchasing activities in Malaysia. Department of Environment, Kuala Lumpur, Malaysia.

Haghnazar, M.A. and M. Sepehri, 2010. Client's critical success factors in outsourcing of construction projects- case study: Tehran municipality. Proceedings of the 5th Scientific Conference on Project Management, May 29-31, Crete, Greece.

Haponava, T. and S. Al-Jibouri, 2010. Establishing influence of design process performance on endproject goals in construction using process-based model. Benchmark.: Int. J., 17: 657-676. DOI: $10.1108 / 14635771011076425$

Hodson, R., 2002. Worker participation and teams: New evidence from analyzing organizational ethnographies. Econ. Indu. Democracy, 23: 491528. DOI: $10.1177 / 0143831 X 02234003$

Karlson, C.H., R. Stephens, C. Desha and H.S. Michael, 2008. A primer series for sustainable design charrettes. Built Environ., 1: 2-20.

Kibert, C., 2007. Sustainable Construction: Green Building Design and Delivery. 2nd Edn., John Wiley and Sons, USA., ISBN-10: 0470114215, pp: 432.

Knudstrup, M.A. and H.T.R. Hansen, 2005. The Integrated Design Process (IDP): A More Holistic Approach to Sustainable Architecture. Arkitektur and Design, Aalborg.
Kometa, S.T., D. Proverbs and P.O. Olomolaiye, 1997. An evaluation of construction Clients' effort in achieving their project needs. University of Wolverhampton.

Kometa, S.T., P.O. Olomolaiye and F.C. Harris, 1996. A review of client-generated risks to project consultants. Int. J. Project Manage., 14: 273-279.

Landman, M., 1999. Breaking through the barriers to sustainable building: Insights from building professionals on government initiatives to promote environmentally sound practices. Tufts University.

Linacre, J. M., 2006. Winsteps Rasch measurement.

Ling, F.Y.Y., 2004. How project managers can better control the performance of design-build projects. Int. J. Project Manage., 22: 477-488.

Love, P., 2002. Influence of Project type and procurement method on rework costs in building construction projects. J. Const. Eng. Manage., 128: 18-29. DOI: 10.1061/(ASCE)07339364(2002)128:1(18)

Mayor, H.R. and L.M. Tormenta, 1999. High Performance Building. 1st Edn., Unpublished Manuscript, New York.

Megat, A.A., 2006. The limitations and opportunities to implement environmental management system in Malaysia. Jurnal Alam Bina., 8: 126-136.

Newton, A., 2008a. The need for more effective design management.

Newton, A., 2008b. What is effective design management?

Nguyen, T.H., J.S. Sherif and M. Newby, 2007. Strategies for successful CRM implementation. Inform. Manage. Comput. Secu., 15: 102-115. DOI: 10.1108/09685220710748001

Owen, C., 2003. The Green Field: The Sub Culture of Sustainable Architecture. 1st Edn., Melbourne University, Melbourne, pp: 470.

Owens, K.A. and A. Halfacr-Heitchcock, 2006. As green as we think? The case of the College of Charleston green building initiative. Int. J. Sustainability Higher Educ., 71: 114-128.

Pheng, L.S. and Q.T. Chuan, 2006. Environmental factors and study performance of project managers in the construction industry. Int. J. Project Manage., 24: 24-37. DOI: 10.1016/j.ijproman.2005.06.001

Rahmat, I., 1997. The Planning and Control Process of Refurbishment Projects. University London, London.

Rounce, G., 1998. Quality, waste and cost considerations in architectural building design management. Int. J. Project Manage., 161: 123127. DOI: $10.1016 / \mathrm{S} 0263-7863: 00042-2$ 
Shafii, F. and M.Z. Othman, 2007. Sustainable building in the Malaysian context. Proceedings of the International Conference on Sustainable Building Asia, Jun. 27-29, Seoul, Korea, pp: 601-606.

Soetanto, R., D.G. Proverbs and P. Cooper, 2000. The performance of the project coalition in the UK construction industry a conceptual optimisation model. Civil Eng. Dimension, 2: 104-110.

Songer, A.D. and K.R. Molenaar, 1997. Project characteristics for successful public-sector designbuild. J. Constr. Eng. Manag., 123: 34-41.

Tilley, P.A., 2005. Lean design management: A new paradigm for managing the design and documentation process to improve quality? Proceeding of the 13th International Group for Lean Construction Conference, (IGLCC' 05), Sydney, pp: 283-295.

Toor, S.U.R. and S.O. Ogunlana, 2009. Construction professionals' perception of critical success factors for large-scale construction projects. Constr. Innov., 9: 149-167. DOI: $10.1108 / 14714170910950803$
Uhl, C. and A. Anderson, 2001. Green destiny: Universities leading the way to a sustainable future. Bioscience, 51: 36-42.

Vandenberg, R.J. and H.A. Richardson, 1999. The impact of high involvement study processes on organizational effectiveness-a second-order latent variable approach. Group Organ. Manage., 24: 300-339. DOI: 10.1177/1059601199243004

Yahya, I.A. and H.A. Rahman, 2007. Value management in analyzing project brief. Proceeding of the Quantity Surveying International Conference.

Yean, Y.L., 2002. Model for predicting performance of architects and engineers. J. Construction Eng. Manage., 128: 446-455.

$\mathrm{Yu}$, A.T.W. and Q. Shen, 2006. Investigation of critical success factors in construction project briefing by way of content analysis. J. Construction Eng. Manage., 132: 1178-1186.

Yudelson, J., 2008. Green Building Through Integrated Design. 1st Edn., The MC Grow Hill Companies, USA., ISBN-10: 0071546014, pp: 261. 